\title{
Difference of Physiochemical Characteristics Between Citrus Bacterial Canker Pathotypes and Identification of Korean Isolates with Repetitive Sequence PCRs
}

\author{
Yong Hoon Lee ${ }^{1 *}$, Seungdon Lee', Dong Hee Lee ${ }^{1}$, Sang Mi Yu', Junghee Lee ${ }^{1}$, Sunggi Heu ${ }^{1}$, Jae Wook Hyun ${ }^{2}$, \\ Dong Soo Ra ${ }^{1}$ and Eun Woo Park ${ }^{3}$ \\ ${ }^{2}$ Plant Pathology Division, National Institute of Agricultural Science and Technology, RDA, Suwon 441-707, Korea \\ ${ }^{2}$ National Institute of Subtropical Agriculture, Jeju 690-150, Korea \\ ${ }^{3}$ Department of Agricultural Biotechnology and Chemistry, Seoul National University, Seoul 151-921, Korea \\ (Received on March 14, 2008; Accepted on August 19, 2008)
}

The difference of carbon source utilization and fatty acid composition between the pathotypes of Xanthomonas strains, which causing citrus bacterial canker was compared, and the physiochemical characteristics were used to analyze relationship of the strains for the first time. The pattern of several carbon sources utilization and fatty acids composition reliably discriminated the pathotypes of Xanthomonas strains. The dendrogram which was constructed by 95 carbon source utilization profiles differentiated $X$. axonopodis pv. citri $A, A^{*}$ and $A^{w}$ from the other pathotypes. When the dendrogram was drawn by combined analysis of carbon source utilization pattern and fatty acid composition, $X$. axonopodis pv. aurantifolii $\mathrm{B}, \mathrm{C}$ and $X$. axonopodis pv. citrumelo formed a distinct cluster. The difference of carbon source utilization and fatty acid composition could be used effectively for the identification of pathotypes of citrus bacterial canker. The physiochemical characteristics strongly indicated that the strains isolated in Korea belong to $X$. axonopodis pv. citri A type. The cluster analysis by the band patterns of ERIC-, BOX- and REP-PCR allowed the discrimination of the pathotypes isolated from Korea. However, the repPCRs could not differentiate $X$. axonopodis pv. citri A types from $A^{*}$ and $A^{w}$ types. The overall results of metabolic profiles and rep-PCRs strongly indicated that the Korean isolates are $X$. axonopodis pv. citri A type.

Keywords : citrus, diversity, pathotype, Xanthomonas axonopodis

Citrus bacterial canker (CBC) is an economically important disease in many tropical and subtropical countries. Several pathotypes have been described within the genus Xanthomonas primarily distinguished by their geographical origin and host range in addition to certain genotypic characteristics (Brunings and Gabriel, 2003). The most commonly

\footnotetext{
*Corresponding author.

Phone) +82-31-290-0430, FAX) +82-31-290-0406

E-mail) leeyh0@rda.go.kr
}

widespread group of $X$. axonopodis pv. citri strains is the main Asiatic group A, with a host range on all citrus varieties. Two groups of strains with restricted host range have been identified within pathotype A (Verniere et al., 1998). They are found in southwest Asia and Florida State in United States, and designated as X. a. pv. citri $\mathrm{A}^{*}$ and $\mathrm{A}^{\mathrm{w}}$, respectively. $\mathrm{A}^{*}$ and $\mathrm{A}^{\mathrm{w}}$ are closely related to type $\mathrm{A}$ strains (Cubero and Graham, 2002, 2004) but affect only Mexican lime and Alemow. Two other canker types are described in South America, which are known as $X$. axonopodis pv. aurantifolii B and C. Pathotype B has a restricted host range including lemon and Mexican lime, whereas pathotype $\mathrm{C}$ is restricted to Mexican lime. $X$. axonopodis pv. citrumelo $\mathrm{E}$ type was later referred to as citrus bacterial spot (CBS) (Stall and Civerolo, 1993).

The variability among isolates of Xanthomonas causing $\mathrm{CBC}$ has been characterized by using different kinds of methods, such as physiological tests, phage typing, restriction analysis, and serological approaches (Egel et al., 1991; Graham et al., 1990; Hartung, 1992; Pruvost et al., 1992; Verniere et al., 1998). Both Biolog ${ }^{\mathrm{TM}}$ and $\mathrm{MIDI}^{\mathrm{TM}}$, primarily analyzing utilization of carbon sources and composition of fatty acids, respectively, can be useful for the identification of bacterial unknowns. Strains can be grouped according to fatty acid content with the statistical programs associated with software developed for the Microbial Identification System. Several papers indicated that the Xanthomonas pathotypes could be differentiated by carbon source utilization pattern (Schaad et al., 2005; Verniere et al., 1998).

PCR based on repetitive sequences (rep-PCR) have been used effectively for analysis of several species of bacteria (Louws et al., 1994), and for strain identification (Cubero and Graham, 2002). Rep-PCR genomic fingerprinting makes use of DNA primers complementary to highly conserved, repetitive DNA sequences such as the 35-40 bp repetitive extragenic palindromic (REP) sequence, the 124-127 bp enterobacterial repetitive intergenic consensus (ERIC) sequence, and the $154 \mathrm{bp}$ BOX element present in multiple copies in the genomes of most Gram-negative and several 
Gram-positive bacteria (Lupski and Weinstock, 1992; Versalovic et al., 1991). The primers for those repetitive sequences leads to the selective amplification of distinct genomic regions located between REP, ERIC or BOX elements. The rep-PCRs have also been used to assess variation among pathovars of Xanthomonas species (Cubero and Graham, 2002; Louws et al., 1994, 1995; Opgenorth et al., 1996).

In this paper, we describe the difference of carbon source utilization and fatty acid composition between the pathotypes of Xanthomonas strains. The difference of carbon source utilization and fatty acid composition was clustered for the first time to separate the CBC pathotypes. RepPCRs with ERIC, BOX and REP primers in order to compare genetic relationship and distribution of Xanthomonas strains isolated in Korea were also performed. These methods allowed us to evaluate the diversity of Xanthomonas strains collected from symptomatic citrus plants in Korea and to relate them to a worldwide collection.

\section{Materials and Methods}

Isolation and identification of bacteria. Diseased samples of citrus plants were collected from 1997 to 2005 in the southern parts of Korea, including the Jeju island. Small pieces of the tissue at the lesion margin were excised with a sterilized razor blade, and the pieces were chopped in a drop of sterile distilled water. The resulting suspension was streaked on nutrient agar or yeast peptone glucose agar ( $0.5 \%$ yeast extract, $0.5 \%$ peptone, $1 \%$ glucose and $1.5 \%$ agar), the single colonies were picked 3 days after incubation at $30^{\circ} \mathrm{C}$. The isolated Xanthomonas strains were tested for their pathogenicity on Citrus paradisi (grapefruit) and C. unshiu (mandarin) at concentrations of $10^{5} \mathrm{cfu} / \mathrm{ml}$ and for their hypersensitive reaction on pepper and tobacco at concentrations of $10^{8} \mathrm{cfu} / \mathrm{ml}$. All inoculated plants were kept in greenhouse with an average temperature of $26^{\circ} \mathrm{C}$. The CBC strains including CBS of which the pathotype was already known were obtained as reference strain from several institutes as described in Table 1.

Carbon source utilization. Pure cultures of the strains were tested for utilization of the 95 carbon sources available on the GN Microplate (Biolog Inc., USA) as recommended by the manufacturer's manual. The carbon source utilization patterns were read with a microplate

Table 1. Strains of Xanthomonas axonopodis used in this study

\begin{tabular}{|c|c|c|c|}
\hline Type & Name & Origin & Source $^{a}$ \\
\hline \multirow[t]{8}{*}{$X$. a. pv. citri $\mathrm{A}$} & CFBP2859 & Brazil & CIRAD \\
\hline & JH410-1 & China & CIRAD \\
\hline & C43, CFBP1814 & France & CIRAD \\
\hline & CFBP2900 & Japan & CIRAD \\
\hline & JJ238-3, JK4-3 & Korea & CIRAD \\
\hline & CFBP2525 & New Zealand & CIRAD \\
\hline & JK148-2 & Philippines & CIRAD \\
\hline & M9, A-5246, M5, A-5208 & USA & DPI \\
\hline \multirow[t]{4}{*}{ X. a. pv. citri $\mathrm{A}^{*}$} & IR01, IR02, IR03, IR04 & Iran & PPDSI \\
\hline & JF90-2 & Oman & CIRAD \\
\hline & JK2-10 & Saudi Arabia & CIRAD \\
\hline & A-1609 & USA & DPI \\
\hline X. a. pv. citri $\mathrm{A}^{\mathrm{w}}$ & A-2032 & USA & DPI \\
\hline$X$. a. pv. aurantifolii B & CFBP2868, CFBP2903 & Argentina & CIRAD \\
\hline$X$. a. pv. aurantifolii $\mathrm{C}$ & CFBP2866 & Brazil & CIRAD \\
\hline X. a. pv. citrumelo (CBS) & XC05-252, A-1902, A-1887 & USA & DPI \\
\hline \multirow[t]{2}{*}{ Korean isolates } & $\begin{array}{l}\text { SL-0870, 0874, 4021, 4024, 4026, 4028, 4029, 4034, 4036, 4040, 4041, 4042, } \\
\text { 4043, 4044, 4045, 4046, 4047, 4049, 4050, 4052, 4054, 4056, 4057, 4059, 4060, } \\
\text { 4062, 4063, 4064, 4066, 4067, 4068, 4070, 4071, 4072, 4073, 4090, 4091, 4093, } \\
\text { 4095, 4096, 4098, 4099, 4100, 4468, 4469, 4474, 4477, 4478, 4483, 4484, 4492, } \\
\text { 4493, 4500, 4501, 4510, 4511 4516, 4517, 4518, 4519, 4520, 4525, 4526, 4528, } \\
\text { 4529, 4530, 4537, 4538, 4539, 4547, 4548, 4553, 4554, 4556, 4558, 4560, 4562, } \\
\text { 4564, 4566, 4567, 4568, 4915, 4916, 4917, 4918, 4920, 4922, 4925, 4926, 4928, } \\
\text { 4931, 4932, 4933, 4934, 4935, 4937, 4943, 4945, 4946, 4947, 4949, 4950, 4952, } \\
\text { 4953, 4954, 4955, 4956, 4958, 4990,4993, 4995 }\end{array}$ & Korea & PPD \\
\hline & KACC10443 & Korea & KACC \\
\hline
\end{tabular}

${ }^{\mathrm{a}}$ CIRAD; The Agricultural Research Centre for International Development, DPI; Division of Plant Industry, Florida, USA, PPD; Plant Pathology Division, NIAST, Korea, PPDSI; Plant Pests and Diseases Research Institute, Iran, KACC; Korean Agricultural Culture Collection 
reader and analyzed for the differentiation of $X$. axonopodis strains by a cluster analysis program, the fingerprinting II informatix $^{\mathrm{TM}}$ software (Bio-Rad, Hercules, CA, USA).

Fatty acid analysis. Fatty acid profiles were generated for the selected strains. All bacterial cultures were grown on trypticase soy broth agar (BBL laboratories, Cockeysville, $\mathrm{MD})$ at $28^{\circ} \mathrm{C}$ for $24 \mathrm{hr}$. Whole-cell fatty acid methyl esters (FAMEs) were extracted and characterized as described previously (Graham et al., 1990). All numerical analysis for the FAME were pooled and subjected to the cluster analysis using the fingerprinting II informatix ${ }^{\mathrm{TM}}$ software.

Extraction of genomic DNA. Total genomic DNA was extracted as described by Shiotani et al. (2000) with small modification. Xanthomonas strains were cultured on peptone sucrose agar (1\% polypeptone, $1 \%$ sucrose and $0.2 \%$ L-glutarmate) or LB media at $28^{\circ} \mathrm{C}$ for 2 days, and the cells were harvested for total DNA extraction. Bacterial cells were washed twice with $5 \mathrm{M} \mathrm{NaCl}$ and suspended in $600 \mu \mathrm{l}$ of Tris-EDTA (TE) buffer (pH 8.0) (Sambrook et al., 1989) containing SDS and proteinase $\mathrm{K}$ at a final concentration of $2 \%$ and $250 \mathrm{ug} / \mathrm{ml}$, respectively. After incubation at $37^{\circ} \mathrm{C}$ for $1 \mathrm{~h}, 100 \mu \mathrm{l}$ of $5 \mathrm{M} \mathrm{NaCl}$ was added to the solution and mixed thoroughly following incubation. Eighty microliters of cetyltrimethylammoniumbromide (CTAB)-NaCl solution $(10 \%$ hexadecyltrimethyl ammonium bromide in 0.7 $\mathrm{M} \mathrm{NaCl}$ ) was added to the solution, which was mixed thoroughly and incubated at $65^{\circ} \mathrm{C}$ for $10 \mathrm{~min}$. DNA was extracted using phenol chloroform isoamyl alcohol (25:24: 1) and precipitated by the addition of 2 vol. of ethanol, and washed with $70 \%$ ethanol. Pelleted DNA was dried in a vacuum and dissolved in distilled water.

DNA amplification conditions for PCR. CBC strains as described in Table 1 were analyzed and compared with reference strains. And the isolated DNAs were used as the templates. BOX-PCR was carried out in $25 \mu \mathrm{l}$ mixtures containing $1 \mathrm{X}$ Taq buffer, $2 \mathrm{mM} \mathrm{MgCl}_{2}, 4 \mu \mathrm{M}$ primer BOX1R (Louws et al., 1994), each deoxynucleoside triphosphate (dNTP) at a concentration of $0.25 \mathrm{mM}$, and $2 \mathrm{U}$ of EX-Taq polymerase (Takara); the amplification conditions consisted of $94^{\circ} \mathrm{C}$ for $1 \mathrm{~min}, 52^{\circ} \mathrm{C}$ for $1 \mathrm{~min}$, and $65^{\circ} \mathrm{C}$ for 8 min for 30 cycles plus an initial step of $94^{\circ} \mathrm{C}$ for $7 \mathrm{~min}$ and a final step of $72^{\circ} \mathrm{C}$ for $10 \mathrm{~min}$. ERIC-PCR was carried out in $25 \mu \mathrm{l}$ mixtures containing $1 \mathrm{X}$ Taq buffer, $2 \mathrm{mM} \mathrm{MgCl}, 2$ $\mu \mathrm{M}$ primer ERIC1R, $2 \mu \mathrm{M}$ primer ERIC2 (Louws et al., 1994), each dNTP at a concentration of $0.25 \mathrm{mM}$, and $2 \mathrm{U}$ of EX-Taq polymerase; the amplification conditions were the same as those used for the BOX-PCR excepting the extension at $50^{\circ} \mathrm{C}$. REP-PCR was also carried out in $25 \mu \mathrm{l}$ mixtures containing $1 \mathrm{X}$ Taq buffer, $2 \mathrm{mM} \mathrm{MgCl}_{2}, 50 \mu \mathrm{M}$ primer of REP1R-I and REP2-I, each dNTP at a concentration of $1.25 \mathrm{mM}$, and $2 \mathrm{U}$ of EX-Taq polymerase; the amplification conditions were the same as those used for the BOX-PCR excepting the extension at $45^{\circ} \mathrm{C}$. The PCR products were analyzed by $1.5 \%$ agarose gel electrophoresis in $1 \mathrm{X}$ TBE buffer at $50 \mathrm{~V}$ and stained with ethidium bromide.

Data analysis. BOX-, ERIC-, and REP-PCR fingerprinting results were compared based on the presence or absence of fragments at a specific position ( 0 absence or negative; 1 presence or positive), and similarity coefficients for pairs of strains were calculated with the program NTSYS, version 2.1 (Rohlf, 2000) and clustered with UPGMA method (unweighted pair group method with arithmetic mean) to determine the genetic relationship among bacterial strains. The FA composition and carbon source utilization pattern was analyzed together using the fingerprinting II informatix ${ }^{\mathrm{TM}}$ software. A dendrogram was constructed by using UPGMA method.

\section{Results}

Identification of bacterial strains. The Xanthomonas strains of which the pathotype was already known were obtained from several institutes as described in Table 1. One hundred and twelve isolates of the pathogen were recovered from leaf and fruit samples collected from symptomatic citrus plants in Korea. No isolates were recovered in other regions of Korea except Jeju island, which is located southern part of Korea. The colonies were mucoid,

Table 2. Oxidation of carbon sources by different pathotypes of $\mathrm{CBC}$ and $\mathrm{CBS}$

\begin{tabular}{lcccccc}
\hline \multirow{2}{*}{ Carbohydrate } & \multicolumn{7}{c}{ CBC pathotype } & CBS \\
\cline { 2 - 6 } & $\mathrm{A}$ & $\mathrm{A}^{*}$ & $\mathrm{~A}^{\mathrm{w}}$ & $\mathrm{B}$ & $\mathrm{C}$ & \\
\hline Glycogen & $100^{\mathrm{a}}$ & 100 & 100 & 0 & 0 & 100 \\
Dextrin & 100 & 100 & 100 & $\mathrm{v}$ & $\mathrm{v}$ & 100 \\
Maltose & 100 & 100 & 100 & 0 & 0 & 100 \\
L-Fucose & 100 & 85.7 & 100 & 0 & 100 & 100 \\
D-Galactose & 100 & 100 & 100 & 0 & 100 & 100 \\
D-Saccharic acid & $\mathrm{v}$ & 0 & 0 & 100 & $\mathrm{v}$ & 0 \\
Tween 40 & 1.8 & 0 & 0 & 0 & 0 & 100 \\
Leucine & $\mathrm{v}$ & $\mathrm{v}$ & 0 & 0 & $\mathrm{v}$ & 100 \\
\hline
\end{tabular}

a Percentage of strains with positive results from all of the strains in Table 1. v; variable but negligible, some strains used slowly but the change of color was negligible. Representative carbon sources which showing distincitive difference are listed. The carbon source utilization patterns on the GN microplate were read with a microplate reader. A, $X$. axonopodis pv. citri A strain; $\mathrm{A}^{*}, X$. a. pv. citri $\mathrm{A}^{*}$ strain; $\mathrm{A}^{\mathrm{w}}, X$. a. pv. citri $\mathrm{A}^{\mathrm{w}}$ strain; $\mathrm{B}, \mathrm{C}, X$. a. pv. aurantifolii strains; and CBS, $X$. a. pv. citrumelo E strain. 


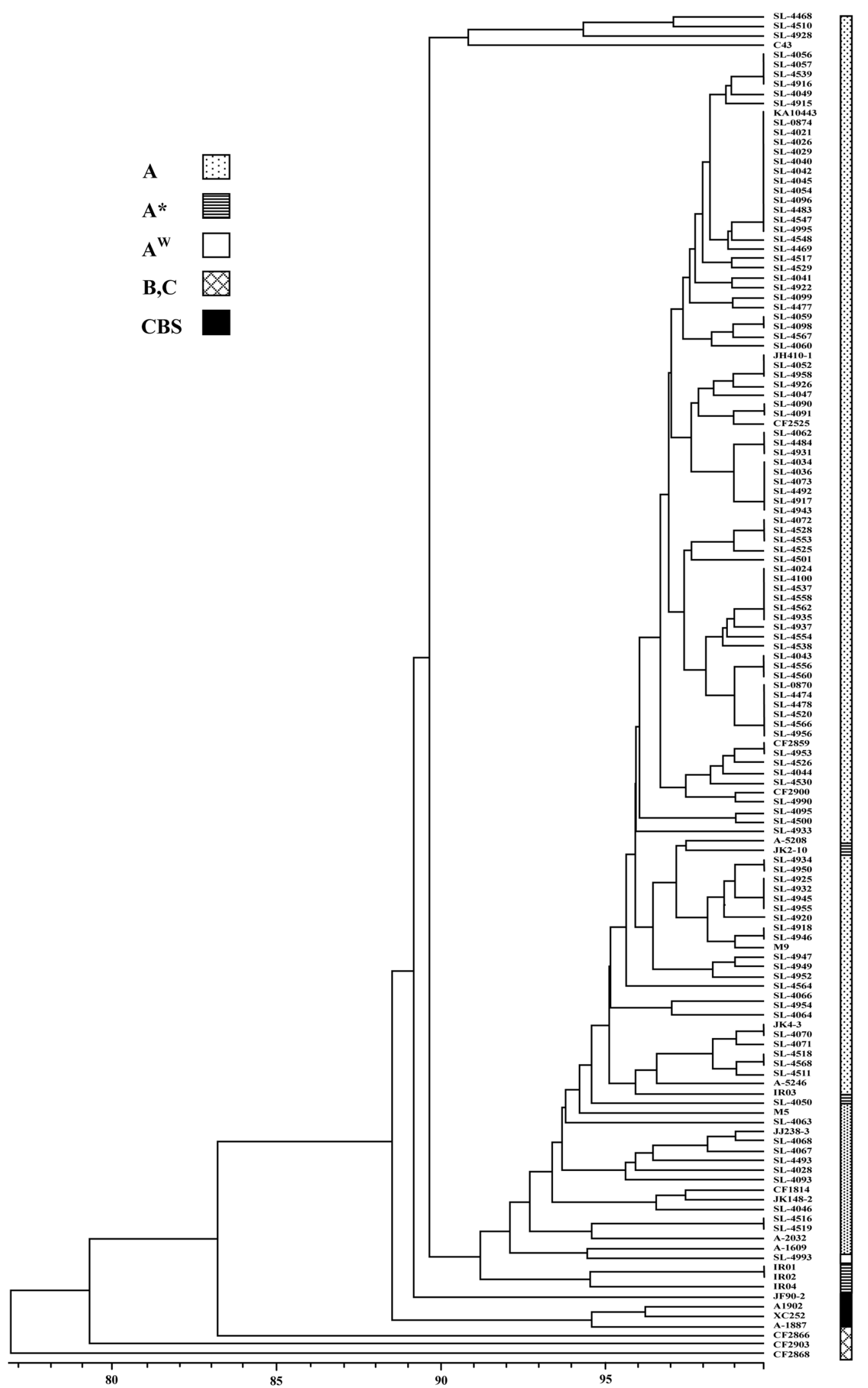

Fig. 1. Dendrogram showing relationship between Xanthomonas strains by carbon source utilization pattern. The data was analyzed by the fingerprinting II informatix ${ }^{\mathrm{TM}}$ software. The lines indicate the $\mathrm{CBC}$ group as follows, $\mathrm{A} ; X$. axonopodis pv. citri A type, $\mathrm{A}^{*} ; X$. $a$. pv. citri $\mathrm{A}^{*}$ type, $\mathrm{A}^{\mathrm{w}} ; X$. a. pv. citri $\mathrm{A}^{\mathrm{w}}$ type, $\mathrm{B}$ and $\mathrm{C} ; X$. a. pv. aurantifolii $\mathrm{B}$ and $\mathrm{C}$ type, and $\mathrm{CBS} ; X$. $a$. pv. citrumelo E type. 
Table 3. Difference of fatty acid profiles depending on the strains of CBC and CBS

\begin{tabular}{|c|c|c|c|c|c|c|}
\hline \multirow{2}{*}{ Fatty acid ${ }^{a}$} & \multicolumn{5}{|c|}{ CBC pathotype } & \multirow{2}{*}{ CBS } \\
\hline & A & $\mathrm{A}^{*}$ & $\mathrm{~A}^{\mathrm{w}}$ & $\mathrm{B}$ & $\mathrm{C}$ & \\
\hline 11:0 ISO & $4.9 \pm 1.04$ & $2.8 \pm 0.29$ & $2.8 \pm 0.39$ & $4.7 \pm 0.38$ & $3.4 \pm 0.22$ & $3.7 \pm 0.19$ \\
\hline 13:0 ISO $3 \mathrm{OH}$ & $5.9 \pm 1.40$ & $2.6 \pm 0.13$ & $2.5 \pm 0.41$ & $6.3 \pm 0.22$ & $5.7 \pm 0.34$ & $3.5 \pm 0.07$ \\
\hline 15:0 ISO & $9.8 \pm 0.64$ & $12.7 \pm 1.19$ & $13.9 \pm 0.88$ & $8.9 \pm 0.34$ & $6.6 \pm 0.17$ & $8.9 \pm 1.01$ \\
\hline 15:0 ANTEISO & $18.8 \pm 1.44$ & $13.9 \pm 1.21$ & $12.3 \pm 8.10$ & $28.8 \pm 5.52$ & $28.0 \pm 1.39$ & $17.4 \pm 0.97$ \\
\hline $16: 1 \mathrm{w} 7 \mathrm{c}$ & $5.5 \pm 1.17$ & $10.9 \pm 0.92$ & $10.9 \pm 2.34$ & $3.3 \pm 2.40$ & $2.2 \pm 0.57$ & $9.3 \pm 0.30$ \\
\hline $16: 0$ & $13.3 \pm 1.19$ & $17.1 \pm 1.07$ & $20.1 \pm 0.11$ & $13.0 \pm 3.16$ & $8.7 \pm 0.59$ & $19.0 \pm 0.95$ \\
\hline ISO $17: 1$ w9c & $11.6 \pm 1.65$ & $8.4 \pm 1.35$ & $5.6 \pm 0.11$ & $6.7 \pm 1.82$ & $13.9 \pm 1.19$ & $8.9 \pm 0.69$ \\
\hline $17: 0$ ISO & $6.9 \pm 0.60$ & $4.1 \pm 0.77$ & $2.4 \pm 0.67$ & $8.6 \pm 3.17$ & $15.2 \pm 0.71$ & $4.2 \pm 0.39$ \\
\hline
\end{tabular}

${ }^{a}$ 11:0 ISO, 9-methyldecanoic acid; 13:0 ISO 3OH, 3-hydroxy-11-methyldodecanoic acid; 15:0 ISO, 13-methyltetradecanoic acid; 15:0 ANTEISO, 12-methyltetradecanoic acid; 16:1 w7c, cis-9-hexadecanoic acid; 16:0, hexadecanoic acid; ISO 17:1 w9c, cis-7-15-methylhexadecanoic acid; 17:0 ISO, 15-methylhexadecanoic acid. Representative fatty acids showing distinctive difference are listed.

convex, and yellow, which indicating that they produced yellow pigment and extracellular polysaccharide on nutrient agar plates as other xanthomonads. Pathogenicity and hypersensitive reaction of the isolated strains were confirmed as described in materials and methods. And they were identified into species by fatty acid and metabolic profile using MIDI and Biolog, respectively.

Difference of carbon source utilization. The pattern of 95 carbon source utilization depending on the $\mathrm{CBC}$ pathotypes was compared using Biolog GN microplate. Glycogen, dextrin, and maltose were used by $\mathrm{A}, \mathrm{A}^{\mathrm{w}}, \mathrm{A}^{*}$ type and CBS, but not by $X$. a. pv. aurantifolii B and $\mathrm{C}$ type (Table 2). Saccharic acid was oxidized only by $X$. a. pv. aurantifolii B type, and galactose was not used only by $X$. $a$. pv. aurantifolii $\mathrm{B}$ type. Tween 40 and leucine was utilized only by $X$. a. pv. citrumelo E type with negligible variation in other pathotypes, which means that the pathotype can be readily differentiated by the tween 40 and leucine. Overall, it was not possible to differentiate $\mathrm{A}, \mathrm{A}^{*}$ and $\mathrm{A}^{\mathrm{w}}$ types by the pattern of carbon source utilization. However, $X$. a. pv. aurantifolii $\mathrm{B}, \mathrm{C}$ type, and CBS can be readily differentiated from the A group by the pattern of several carbon sources. When Xanthomonas pathotypes were differentiated by analysis of carbon source utilization pattern (Fig. 1), bacterial strains of $X$. $a$. pv. aurantifolii $\mathrm{B}, \mathrm{C}$ types and $X$. $a$. pv. citrumelo were discriminated from $X$. a. pv. citri A, A* and $\mathrm{A}^{\mathrm{w}}$ strains with around $89 \%$ similarity. The $X . a$. pv. citri $\mathrm{A}^{*}$ and $\mathrm{A}^{\mathrm{w}}$ were clustered in the same group with $X . a$. pv. citri A by the analysis.

Difference of fatty acid composition. The fatty acids which show more than two times difference depending on the pathotypes of Xanthomonas are listed in Table 3. Several fatty acids such as 9-methyldecanonic acid, 3hydroxy-11-methyldodecanoic acid, 9-hexadecanoic acid and 15-methylhexadecanoic acid can be used to differ- entiate X. a. pv. citri $\mathrm{A}^{*}$ and $\mathrm{A}^{\mathrm{w}}$ types from $\mathrm{A}$ types. And 12methyltetradecanoic acid and cis-9-hexadecanoic acid can be used to detect $X$. $a$. pv. aurantifolii $\mathrm{B}$ and $\mathrm{C}$ type. There was a clear difference in 15-methylhexadecanoic acid and cis-7-15-methylhexadecanoic acid composition between $X$. a. pv. aurantifolii B and C types. The Xanthomonas pathotypes were not clearly differentiated by 50 fatty acid composition with the cluster analysis program (data not shown). When the fatty acid composition was analyzed together with carbon source utilization pattern, bacterial strains of $X$ a. pv. aurantifolii $\mathrm{B}, \mathrm{C}$ type and $X$. a. pv. citrumelo E type formed a distinct cluster (Fig. 2).

\section{Xanthomonas strains causing $\mathrm{CBC}$ classified by rep-} PCRs. Different fingerprints were generated by the products of BOX-, ERIC-, and REP-PCR. The primers corresponding to the each conserved repetitive sequences yielded PCR products ranging from approximately 100 to 40,000 bp under our PCR conditions. Cluster analysis of the data obtained from ERIC-PCR revealed two major clusters (Fig. 3). One cluster included all $X$. a. pv. citri isolates with $75 \%$ similarity and the other cluster contained all of the $X . a$. pv. aurantifolii isolates and the $X . a$. pv. citrumelo $\mathrm{E}$ isolates were located between the two major groups. The mean level of similarity of the tested strains was $43 \%$. The Korean isolates grouped differently from the $X$. a. pv. citri $\mathrm{A}^{*}$ and $\mathrm{A}^{\mathrm{w}}$, and the similarity between them was above $90 \%$.

Analysis of the fingerprints of BOX elements yielded two main clusters, one that included all $X . a$. pv. citri and $X$. $a$. pv. aurantifolii strains, and one that included $X . a$. pv. citrumelo strains; the mean level of similarity between the two main clusters was $43 \%$ (Fig. 4). The $X$. a. pv. citri, $X$. a. pv. aurantifolii $\mathrm{B}$ and $\mathrm{C}$ which were included in the same main group were clearly discerned with about $50 \%$ similarity. The $X . a$. pv. citri A type could not be differentiated from $A^{*}$ and $A^{w}$ strains with some variation, and 

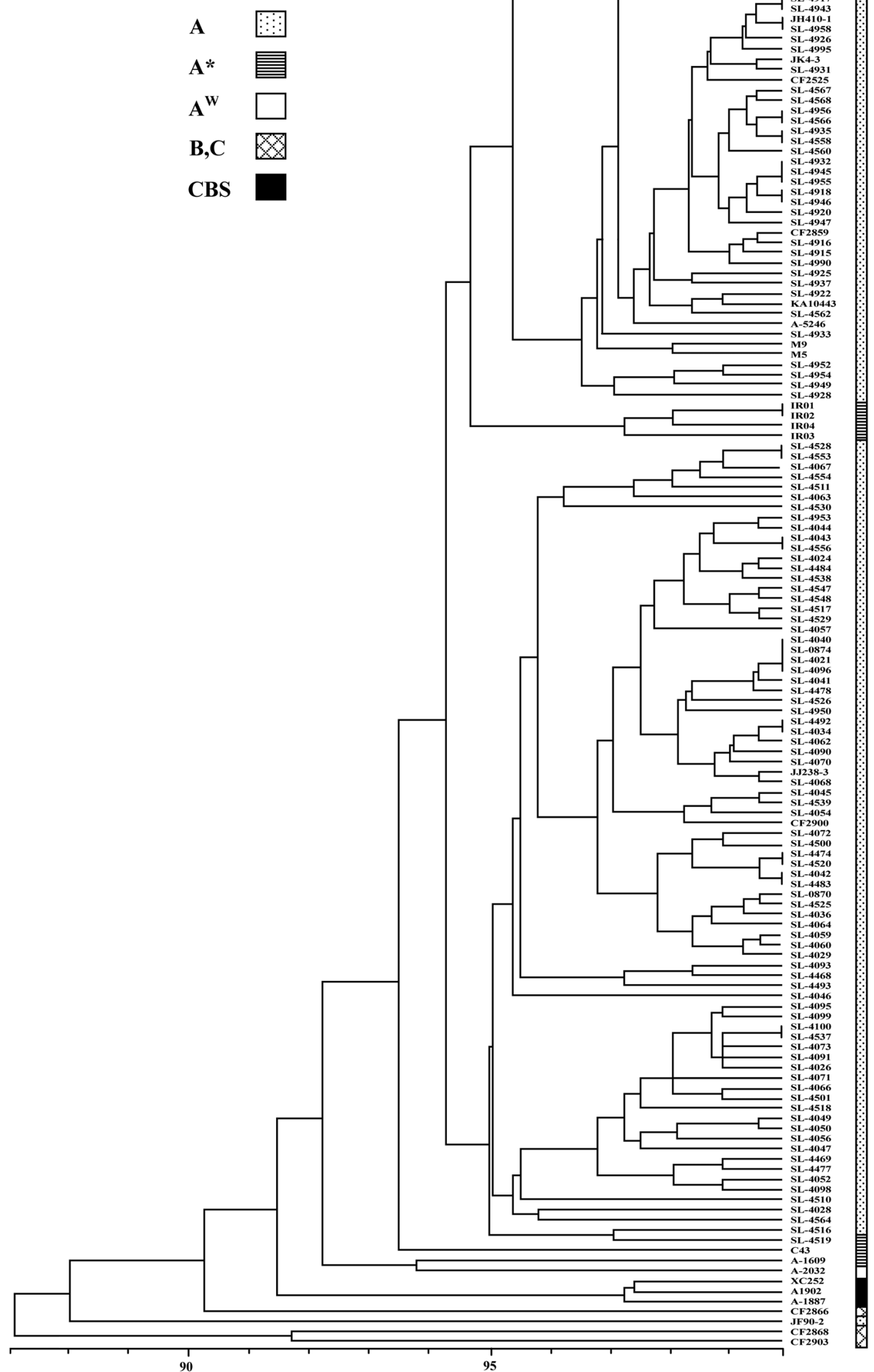

Fig. 2. Dendrogram showing relationship between Xanthomonas strains by combined analysis metabolic and fatty acid profiles. The data of carbon source utilization and composition of fatty acid were combined and analyzed using the fingerprinting II informatix ${ }^{\mathrm{TM}}$ software. 


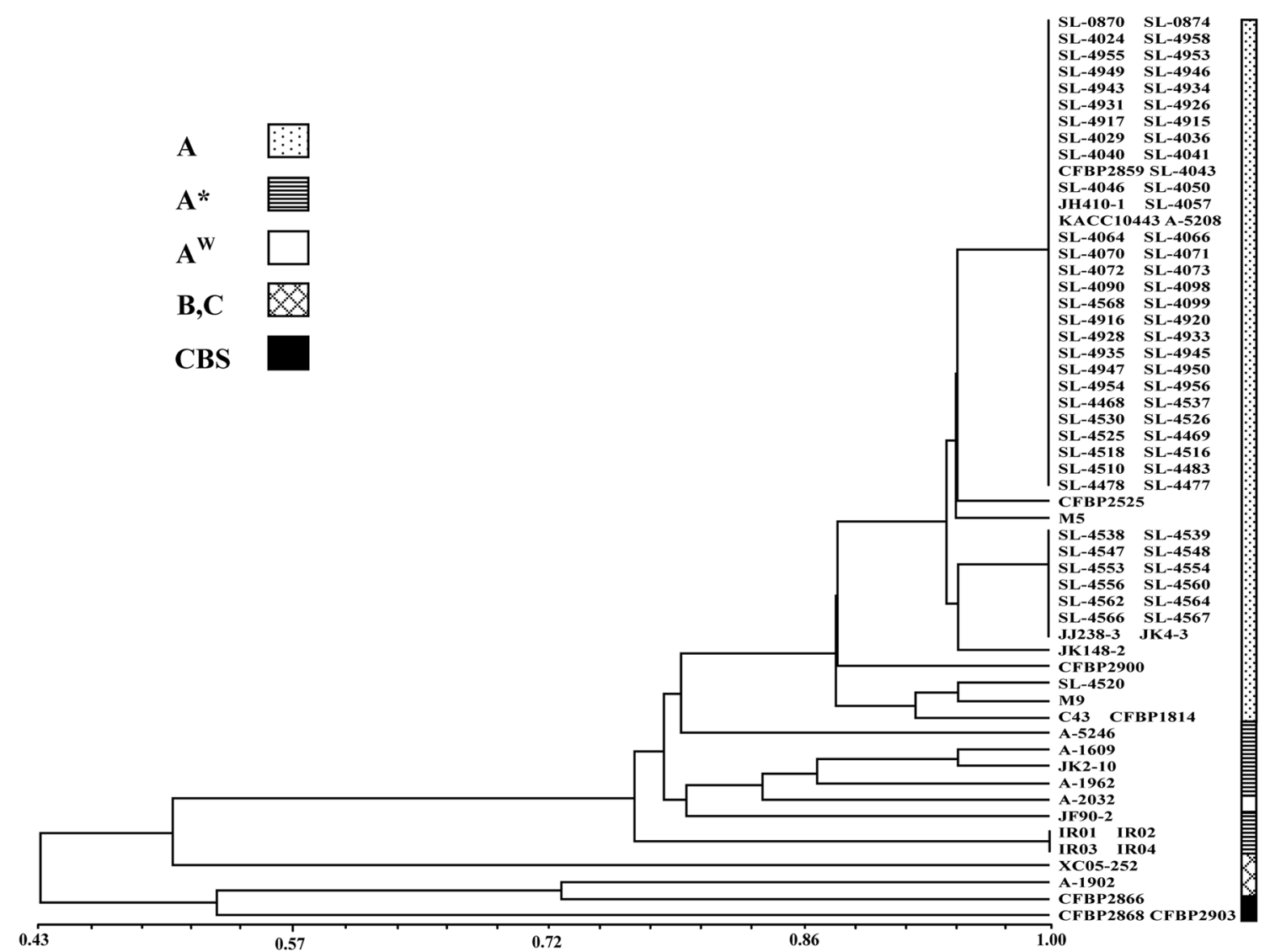

Fig. 3. Dendrogram showing relationships between Xanthomonas causing CBC based on ERIC-PCR analysis. Similarities were calculated by using the Dice coefficient, and clustering was achieved by UPGMA using the NTSYS version 2.1.

most of Korean isolates had above $80 \%$ similarity. The fingerprinting clusters by REP sequences separated the tested pathotypes into two main groups with $59 \%$ similarity (Fig. 5). One that included $X$. a. pv. aurantifolii B and one that included all of the other tested strains. In one group, the $X$. a. pv. citrumelo discerned from the other groups with a approximate $70 \%$ similarity, and $X$. a. pv. aurantifolii pathotype $\mathrm{C}$ was also differentiated from the $X$. $a$. pv. citri with a similarity about $75 \%$. However, the $X$. a. pv. citri A, $\mathrm{A}^{*}$ and $\mathrm{A}^{\mathrm{w}}$ was not clearly discerned by the REP sequence analysis.

\section{Discussion}

Taxonomic information can be acquired by examining the carbon source utilization profile of a bacterial strain. In this experiment the $X$. a. pv. aurantifolii B and C type were distinguishable from $X$. a. pv. citri strains by utilization of several carbon sources, such as glycogen, dextrin, and maltose (Table 2). The utilization of maltose depending on the pathotype was exactly same as reported by Schaad et al. (2005). Galactose and alaninamide were used similarly by each pathotypes as the tests of Verniere et al. (1998). They also reported that $76.6 \%$ of the tested A types used fucose, however fucose was used by all of the tested A strains in our study. Schaad et al. (2005) reported that raffinose could not be utilized by $A, A^{*}$ and $A^{w}$ types, but in our experiment there was some variation depending on the strains (data not shown), which needs more investigation. When the relatedness was constructed by 95 carbon source utilization pattern, the Asiatic strains of citrus canker form a discrete cluster, and they distinguished from strains of the CBS pathogen, which formed a separate cluster. In view of the general use of Biolog systems for bacterial identification, determination of carbon source utilization pattern may be a rapid and sensitive method for separation of Xanthomonas strains on citrus if used complementarily with other methods.

Fatty acids extracted from bacterial cells facilitate the identification and quantification of the fatty acid by gas chromatography. The fatty acid by profiles from members of the bacterial genus Xanthomonas are relatively complex compared to those of other plant pathogenic bacteria. The differences in relative quantity of them among strains presented the potential for distinguishing groups of strains 


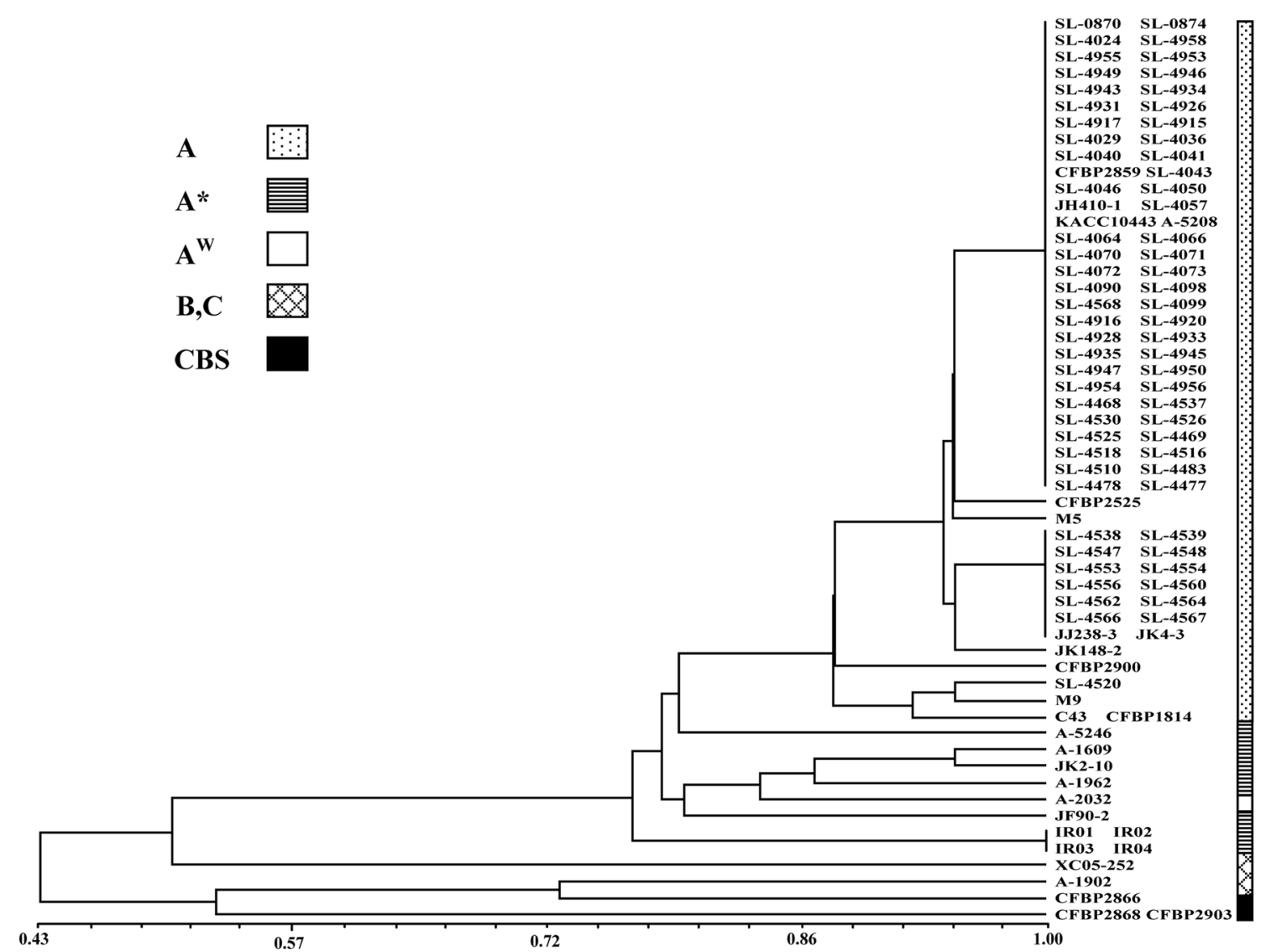

Fig. 4. Dendrogram of relationships based on BOX-PCR analysis. Similarities were calculated by using the Dice coefficient, and clustering was achieved by UPGMA using the NTSYS version 2.1 .

within the genus as shown in Table 2. Though $X$. a. pv. aurantifolii $\mathrm{B}, \mathrm{C}$ and $X$. a. pv. citrumelo $\mathrm{E}$ was not clearly differentiated in the dendrogram by fatty acid composition (data not shown), when the fatty acid composition was analyzed together with carbon source utilization pattern, bacterial strains of $X$. a. pv. aurantifolii $\mathrm{B}, \mathrm{C}$ types and $X$. $a$. pv. citrumelo $\mathrm{E}$ type formed a distinct cluster (Fig. 2). To our knowledge this is the first report on differentiation of CBC pathotypes using combined analysis of carbon source utilization and fatty acid composition. The Korean isolates clustered in the same group as the reference of $X$. $a$. pv. citri A type, which indicating the pathotypes of Korean strains belong to A type.

Several techniques such as RFLP analysis, genomic fingerprinting, and rDNA analysis have been reported for the identification of the bacterial strains and pathotype assignation. Especially, REP-, ERIC-, and BOX-PCR were effectively used to generate genomic fingerprints of a variety of Xanthomonas isolates and to identify pathovars and strains that were previously not distinguishable by other classification methods (Cubero and Graham, 2002; Louws et al., 1994, 1995; Opgenorth et al., 1996). In this experiment most of the bands were present in all tested strains, but there were differences in the intensity of some amplified fragments as well as in the occurrence of several polymorphic bands. The polymorphic bands in the $\mathrm{A}^{*}, \mathrm{~A}^{\mathrm{w}}$, $\mathrm{B}$ and $\mathrm{C}$ types were fewer than those in the A type (data not shown). The $X$. $a$. pv. citri $\mathrm{A}, \mathrm{A}^{*}$ and $\mathrm{A}^{\mathrm{w}}$ strains were clearly separated from the $X$. a. pv. aurantifolii $\mathrm{B}, \mathrm{C}$ and $X$. a. pv. citrumelo $\mathrm{E}$ by all of the primers used. Both ERIC- and BOX-PCR allowed discrimination between the A, $\mathrm{A}^{*}$ and $A^{w}$ groups with slight variation, but our results of rep-PCR also indicated that $\mathrm{A}^{*}$ and $\mathrm{A}^{\mathrm{w}}$ types are close to $\mathrm{A}$ types.

Rep-PCR has revealed both inter and intrapathovar variability (Louws et al., 1994), but a very high degree of homogeneity was found in Xanthomonas, with REP and ERIC primers (Opgenorth et al., 1996). Trindade et al. (2005) reported that the ERIC-PCR revealed more polymorphic bands in $X$. campestris pv. viticola than the other two sets of primers. The REP element was the most conserved and the less efficient in revealing polymorphism in X. c. pv. vesicatoria group B strains (Louws et al., 1995). In this experiment the REP-PCR revealed less polymorphic bands between the tested strains than those of ERIC and 


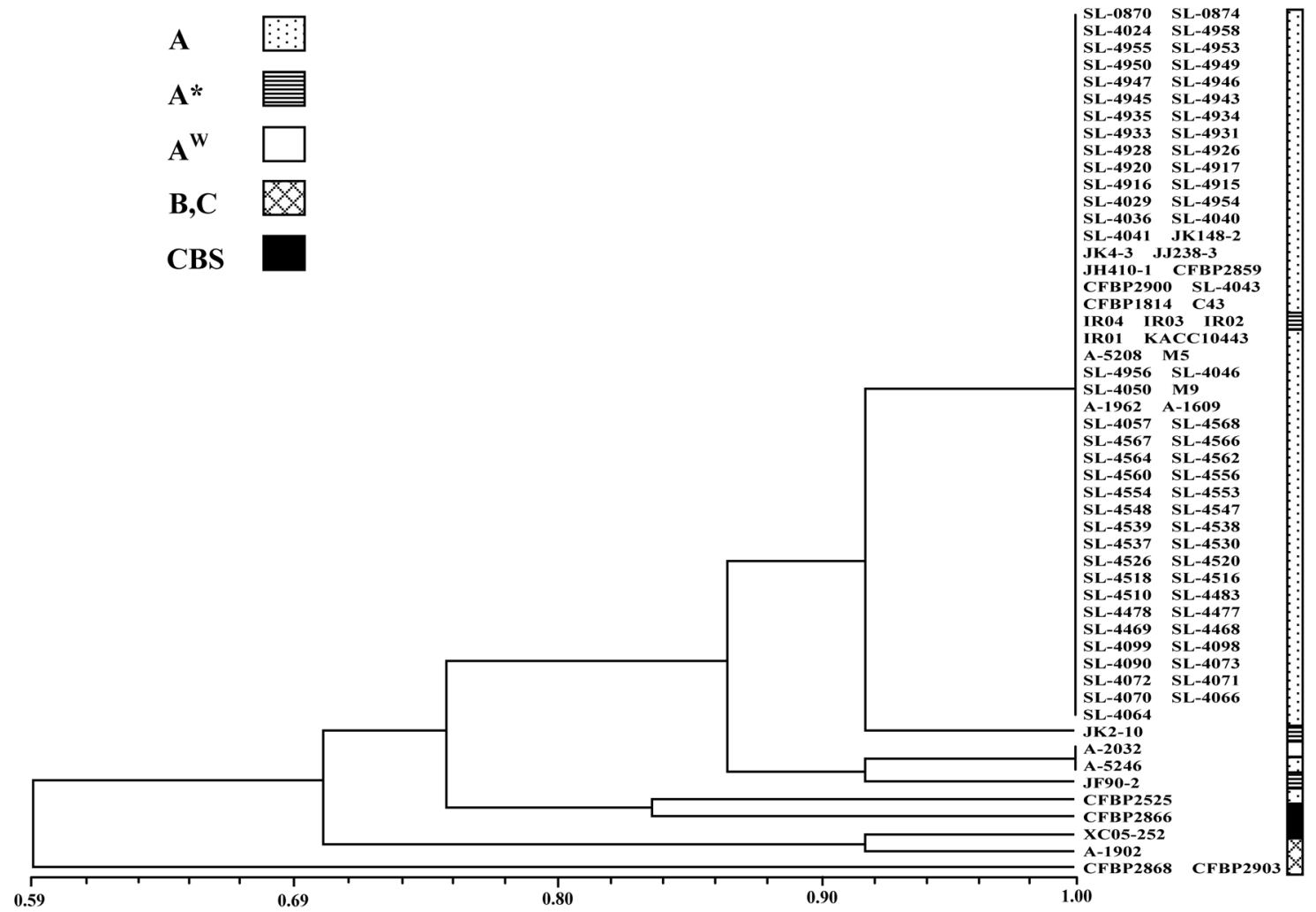

Fig. 5. Dendrogram of relationships based on REP-PCR analysis. Similarities were calculated by using the Dice coefficient, and clustering was achieved by UPGMA using the NTSYS version 2.1.

BOX primers. And REP-PCR, which identifying a smaller number of subgroups among the strains, was also the most conserved of the three sets of primers tested. These results indicate that the polymorphic bands are maybe variable according to PCR conditions but still good tool to identify diverse of pathogens.

Overall our results indicated that differentiation of the pathotypes of $\mathrm{CBC}$ by some of carbon source utilization and fatty acid composition could be used effectively from the isolation and identification step of the pathogen. The rep-PCR fingerprinting can be an important tool for monitoring the diversity of the $\mathrm{CBC}$, which confirming the previous reports. Both the physiochemical characteristics and rep-PCR results significantly indicated that Korean isolates are all $X$. $a$. pv. citri A types.

\section{Acknowledgement}

This research was supported by Agriculture R \& D Promotion Center (ARPC), Ministry of Agriculture and Forestry, Korea, 2005 project (105058-03-2-HD120).

\section{References}

Brunings, A. M. and Gabriel, D. W. 2003. Xanthomonas citri: breaking the surface. Mol. Plant Pathol. 4:141-157.

Cubero, J. and Graham, J. H. 2002. Genetic relationship among worldwide strains of Xanthomonas causing canker in citrus species and design of new primers for their identification by PCR. Appl. Environ. Microbiol. 68:1257-1264.

Cubero, J. and Graham, J. H. 2004. The leucine-responsive regulatory protein ( $l r p$ ) gene for characterization of the relationship among Xanthomonas species. Int. J. Syst. Evol. Microbiol. 54:429-437.

Egel, D. S., Graham, J. H. and Stall, R. E. 1991. Genomic relatedness of Xanthomonas campestris strains causing diseases of citrus. Appl. Environ. Microbiol. 57:2724-2730.

Graham, J. H., Hartung, J. S., Stall, R. E. and Chase, A. R. 1990. Pathological, restriction-fragment length polymorphism, and fatty acid profile relationships between Xanthomonas campestris from citrus and noncitrus hosts. Phytopathology 80:829836.

Hartung, J. S. 1992. Plasmid-based hybridisation probes for detection and identification of Xanthomonas campestris pv. citri. Plant Dis. 76:889-893.

Louws, F. J., Fulbright, D. W., Stephens, C. T. and de Bruijn, F. J. 1994. Specific genomic fingerprints of phytopathogenic Xanthomonas and Pseudomonas pathovars and strains generated with repetitive sequences and PCR. Appl. Environ. Microbiol. 60:2286-2295.

Louws, F. J., Fulbright, D. W., Stephens, C. T. and de Bruijn, F. J. 
1995. Differentiation of genomic structure by rep-PCR fingerprinting to rapidly classify Xanthomonas campestris pv. vesicatoria. Phytopathology 85:528-536.

Lupski, J. R. and Weinstock, G. M. 1992. Short, interspersed repetitive DNA sequences in prokaryotic genomes. J. Bacteriol. 174:4525-4529.

Opgenorth, D. C., Smart, C. D., Louws, F. J., de Bruijn, F. J. and Kirkpatrick, B. C. 1996. Identification of Xanthomonas fragariae field isolates by rep-PCR genomic fingerprintings. Plant Dis. 80:868-873.

Pruvost, O., Hartung, J. S., Civerolo, E. L., Dubois, C. and Perrier, X. 1992. Plasmid DNA fingerprints distinguish pathotypes of Xanthomonas campestris pv. citri, the causal agent of citrus bacterial canker disease. Phytopathology 82:485-490.

Rohlf, F. J. 2000. NTSYSpc: Numerical Taxonomy System, ver. 2.1. New York, Exeter Publishing

Sambrook, J., Fritsch, E. F. and Maniatis, T. (Eds.). 1989. Molecular Cloning: A Laboratory Manual. 2nd ed. New York, Cold Spring Harbor Laboratory.

Schaad, N. W., Postnikova, E., Lacy, G., Sechler, A. J., Agarkova, I., Stromberg, P., Strombuer, V. and Vidaver, A. 2005. Reclassification of Xanthomonas campestris pv. citri (ex Hasse, 1915) 1978 forms A, B/C/D, and E as X. smithii subsp. citri (ex Hasse) nom. rev. comb. nov., X. fuscans subsp. aurantifolii (ex Gabriel, 1989) nov. nom. rev. comb. nov., and X. alfalfae subsp. citrumelo (ex Riker Jones) Gabriel et al., 1989 sp. nov. nom. rev. comb. nov.; $X$. campestris malvacearum (ex Smith
1901) Dye 1978 as $X$. smithii subsp. smithii comb. nov. nom. nov.; X. campestris pv. alfalfae (ex Riker and Jones, 1935) Dye 1978 as X. alfalfae subsp. alfalfae (ex Riker et al., 1935) nov. nom. rev.; and "var. fuscans" of $X$. campestris pv. phaseoli (ex Smith, 1987) Dye 1978 as X. fuscans subsp. fuscans sp. nov. Syst. Appl. Microbiol. 28:494-518.

Shiotani, H., Ozaki, K. and Tsuyumu, S. 2000. Pathogenic interactions between Xanthomonas axonopodis pv. citri and cultivars of pummelo (Citrus grandis). Phytopathology 90:13831389.

Stall, R. E. and Civerolo, E. L. 1993. Xanthomonas campestris pv. citri: cause of citrus canker. In Swings, J.G. and Civerolo, E.L. (Eds.), Xanthomona. London: Chapman and Hall. pp. 48-51.

Trindade, L. C., Lima, M. F. and Ferreira, M. A. S. V. 2005. Molecular characterization of Brazilian strains of Xanthomonas campestris pv. viticola by rep-PCR fingerprinting. Fitopatol. Bras. 30:46-54.

Versalovic, J., Koeuth, T. and Lupski, J. R. 1991. Distribution of repetitive DNA sequences in eubacteria and application to fingerprinting of bacterial genomes. Nucleic Acids Res. 19:68236831.

Verniere, C., Hartung, J. S., Pruvost, O. P., Civerolo, E. L., Alvarez, A. M., Maestri, P. and Luisetti, J. 1998. Characterization of phenotypically distinct strains of Xanthomonas axonopodis pv. citri from Southwest Asia. Eur. J. Plant Pathol. 104:477487. 